\section{PERLINDUNGAN HUKUM BAGI KREDITUR DENGAN OBJEK HAK GUNA BANGUNAN YANG AKAN BERAKHIR MASA BERLAKUNYA SEBELUM PERJANJIAN KREDIT JATUH TEMPO DILIHAT DARI ASPEK HUKUM HAK TANGGUNGAN ${ }^{1}$ Oleh: Yurichty Poppy Suhantri² Friend H. Anis ${ }^{3}$ Deasy Soeikromo ${ }^{4}$}

\begin{abstract}
ABSTRAK
Dari jenisnya, penelitian ini adalah penelitian hukum normatif. Sumber data pada penelitian hukum normatif adalah sekunder yang diperoleh dan dikumpulkan dari bahan hukum primer, bahan hukum sekunder, dan bahan hukum tersier atau penunjang. Bahan hukum yang dikaji dan yang dianalasis dalam penelitian hukum normatif meliputi bahan hukum primer, sekunder dan tersier. Analisis data yang digunakan adalah analisis kualitatif. SKMHT dibuat oleh notaris atau PPAT dan dapat dipergunakan dalam hal pemberi hak tanggungan berhalangan hadir dalam memberikan hak tanggungan dan
\end{abstract} menandatangani APHT sehingga dikuasakan kepada pihak lain. Jangka waktu berlakunya SKMHT adalah satu bulan dalam hal dijadikan objek hak tanggungan hak atas tanah yang sudah didaftar, dan tiga bulan untuk jaminan hak atas tanah yang belum didaftar atau bilamana hak atas tanah yang bersangkutan sudah bersertifikat, tetapi belum tercatat atas nama pemberi hak tanggungan sebagai pemegangnya hak yang baru. Pembebanan hak tanggungan untuk tanah-tanah yang sudah terdaftar (ada sertifikat) didahului dengan pembuatan APHT oleh PPAT, yang kemudian berdasarkan APHT tersebut oleh Kantor Pertanahan dikeluarkan sertifikat hak tanggungan. Untuk tanah-tanah yang belum terdaftar dan tanah-tanah yang berada diluar wilayah kerja kreditur, pembebanan hak tanggungannya adalah dalam bentuk SKMHT yang juga dibuat oleh Notaris/PPAT.

Kata Kunci: Perlindungan Hukum, Hak Guna Bangunan, Perjanjian Kredit, Hak Tanggungan

\footnotetext{
${ }^{1}$ Artikel Tesis.

${ }^{2}$ Mahasiswa pada Pascasarjana Unsrat, NIM. 18202108034

${ }^{3}$ Fakultas Hukum Unsrat, Doktor Ilmu Hukum

${ }^{4}$ Fakultas Hukum Unsrat, Doktor IImu Hukum
}

\section{PENDAHULUAN}

\section{A. Latar Belakang Masalah}

Penyaluran dana pinjaman kredit dilakukan oleh pihak bank selaku lembaga perantara atau penyalur dana kepada masyarakat yang membutuhkan modal, dan penyaluran tersebut dibuat dalam suatu perjanjian sebagai dasar hubungan hukum diantara para pihak (kreditur dan debitur). Adanya perjanjian pinjam meminjam uang tersebut, sehingga diperlukannya solusi hukum dengan adanya lembaga penjamin agar dapat memberikan kepastian bagi pengembalian pinjaman tersebut. Keberadaan lembaga jaminan sangat diperlukan karena dapat memberikan kepastian serta perlindungan hukum bagi penyedia dana / kredit (kreditur) dan penerima pinjaman (debitur) ${ }^{5}$.

Ketika memberikan kredit sebagai fungsi pokok dari bank, maka pemberian kredit harus memperhitungkan agar tidak membahayakan pemenuhan kewajiban kepada nasabah jika sewaktu-waktu diperlukan. Kredit dapat berupa kredit jangka pendek, menengah, dan panjang. Kredit jangka pendek dapat memberi pengaruh langsung terhadap pasar uang, sedangkan kredit jangka menengah dan jangka panjang dapat mempunyai pengaruh langsung terhadap pasar modal. ${ }^{6}$ Dalam perkembangan usaha saat ini, bank merupakan salah satu lembaga keuangan yang sangat berperan aktif dalam membiayai usaha yang ada di dalam masyarakat. Salah satu produk yang diberikan oleh bank dalam membantu kelancaran usaha debitornya adalah pemberian kredit, di mana hal ini merupakan salah satu fungsi bank sebagai modal ekonomi yang sangat mendukung pertumbuhan dan perkembangan ekonomi. Kredit merupakan perjanjian pinjam meminjam uang antara bank sebagai kreditur dengan nasabah sebagai debitur. Dalam perjanjian ini, bank sebagai pemberi kredit percaya terhadap nasabah dalam jangka waktu yang disepakatinya akan dikembalikan (dibayar) lunas. Tenggang waktu antara pemberian dan penerimaan kembali prestasi menurut Mgs. Edy Putra Tje' Aman merupakan suatu hal yang abstrak yang sukar

\footnotetext{
${ }^{5}$ Sony Harsono. 1996. Sambutan Menteri Agraria/ Kepala BPN Dalam Seminar Hak Tanggungan atas Tanah dan Benda-benda yang Berkaitan dengan Tanah. Fakultas Hukum UNPAD. Bandung. 33

${ }^{6}$ Nindyo Pramono. 2006. Hukum Bisnis Aktual. Cetakan Kesatu . Bandung: Citra Aditya Bakti. 212.
} 
diraba, karena masa antara pemberian dan penerimaan prestasi tersebut dapat berjalan dalam beberapa bulan, tetapi dapat pula berjalan beberapa tahun. ${ }^{7}$

Jaminan yang dianggap paling efektif dan aman oleh lembaga perbankan adalah tanah dengan jaminan Hak Tanggungan. Hal ini didasari oleh adanya kemudahan dalam mengidentifikasi objek Hak Tanggungan, eksekusinya jelas dan pasti, disamping itu hutangnya dijamin dengan Hak Tanggungan yang harus dibayar terlebih dahulu dari tagihan lainnya dengan uang hasil dari pelelangan tanah yang menjadi objek Hak Tanggungan, salah satu hal paling penting yang tidak dapat diabaikan dalam perjanjian kredit adalah perlindungan hukum bagi kreditur manakala ketika debitur wanprestasi, apalagi kalau debitur sampai mengalami kemacetan dalam pembayarannya. Manfaat lembaga eksekusi Hak Tanggungan merupakan cara untuk mempercepat pelunasan piutang agar dana yang telah dikeluarkan/ dipinjam itu dapat segera dikembalikan kepada kreditur dalam hal ini adalah Bank, agar dana tersebut dapat digunakan dalam perputaran roda perekonomian ${ }^{8}$.

Awalnya lembaga jaminan atas tanah adalah hipotek dan credietverband. Hipotek diatur dalam Buku II BW Burgelijke Wetboek (selanjutnya disebut B.W.), yang sama dengan Kitab Undang-Undang Hukum Perdata dalam Pasal 1162-1232 BW; sedang credietverband diatur dalam Staatsblaad Tahun 1908 nomr 542 yang diubah menjadi Stb. 1937-190. Sejak berlakunya Undang-Undang no. 5 tahun 1960, menjadikan untuk membuat perangkat peraturan aturan tentang Hak Tanggungan yang baru terealisasi diundangkan pada 9 April 1996, lahirlah UU no. 4 tahun 1996 tentang Hak Tanggungan Atas Tanah Beserta Benda-benda yang berkaitan dengan Tanah (selanjutnya disingkat UUHT) yang selanjutnya disebut Hak Tanggungan.

Sebagai lembaga jaminan, Hak Tanggungan adalah hak jaminan yang dibebankan pada hak atas tanah sebagaimana yang dimaksud dalam

\footnotetext{
${ }^{7}$ Adrian Sutedi. 2006. Implikasi Hak Tanggungan Terhadap Pemberian Kredit Oleh Bank dan Penyelesaian Kredit Bermasalah. Jakarta: Cipta Jaya. 19.

8 Retnowulan Sutantio 1999. Penelitian Tentang Perlindungan Hukum Eksekusi Jaminan Kredit. Jakarta: Badan Pembinaan Hukum Nasional-Departemen Kehakiman RI. 8.
}

Undang-undang No. 5 Tahun 1960, tentang Peraturan Dasar Pokok-pokok Agraria, bendabenda lain yang merupakan satu kesatuan dengan tanah itu, untuk pelunasan utang tertentu, yang memberikan kedudukan yang diutamakan kepada kreditur tertentu terhadap kreditur-kreditur lain ${ }^{9}$.

Perjanjian jaminan yang melahirkan Hak Tanggungan, dibuat oleh para pihak dengan tujuan agar melengkapi perjanjian pokok yang umumnya merupakan perjanjian utang piutang atau perjanjian kredit. Melihat penjelasanpenjelasan seperti diatas dapat diambil suatu pemahaman, bahwa hubungan hukum antara para pihak dijalin oleh 2 (dua) jenis perjanjian, yakni perjanjian kredit sebagai perjanjian pokok dan perjanjian jaminan sebagai jaminan tambahan (accessoir) $^{10}$.

Meskipun Hak Tanggungan sebagai perjanjian jaminan tambahan, akan tetapi fungsinya sebagai pemberi rasa aman bagi kreditur, karena apabila debitur cedera janji/ wanprestasi, kreditur mendapatkan perlindungan hukum, karena benda yang dijaminkan tersebut dapat diuangkan sebagai pelunasan utang dari debitur kepada debitur. Fungsi jaminan secara hukum dipertegas pula oleh Juhaendah Hasan, yakni untuk mengcover hutang, karena jaminan merupakan sarana perlindungan bagi para kreditur yakni kepastian akan pelunasan hutang debitur atau pelaksanaan suatu prestasi oleh debitur atau penjamin debitur, sehingga jaminan yang memberikan sebuah kepastian kepada pihak pemberi kredit, dalam artian bahwa barang jaminan yang dikreditkan setiap waktu tersedia untuk dieksekusi, yaitu bila perlu dapat dengan mudah diuangkan untuk melunasi utang pihak pengambil kredit ${ }^{11}$.

Pemberian kredit yang diberikan oleh Bank sebagai suatu lembaga penyedia dana, sudah seharusnya dapat memberikan perlindungan hukum bagi pihak pemberi dan penerima kredit melalui suatu lembaga perlindungan hukum bagi para pihak yang berkepentingan.

\footnotetext{
${ }^{9}$ Kansil. Pokok-Pokok Hak Tanggungan Atas Tanah. 2009. Jakarta: Pustaka Sinar Harapan. 19-20.

${ }^{10}$ M. Isnaeni. 1999. Kerancuan Hak Tanggungan Dalam Kaitannya Sebagai Pengamanan Penyaluranan Kredit Bank. Jurnal Hukum Hak Tanggungan. Vol. I. Jakarta. 80

11 Juhaenda Hasan. 2000. Aspek Hukum Jaminan Kebendaan dan Perorangan, Jurnal Hukum Bisnis. Nomor 16: 11.23
} 
Tanah merupakan bagian dari permukaan bumi yang merupakan satuan dari bidang-bidang yang memiliki batasan tertentu. Terdapat hak atas tanah dari setiap orang atau badan hukum ${ }^{12}$ diatas setiap bidang tanah yang ada di permukaan bumi ini.

\section{B. Rumusan Masalah}

1. Bagaimana akibat hukum terlaksananya Surat Kuasa Membebankan Hak Tanggungan (SKMHT) dalam perjanjian kredit perbankan?

2. Bagaimana perlindungan hukum terhadap kreditur pemegang Hak Tanggungan yang obyeknya berupa Hak Guna Bangunan, apabila Hak Guna Bangunan tersebut berakhir sedangkan jangka waktu kreditnya belum jatuh tempo?

\section{Tujuan Penelitian}

Berdasarkan latar belakang dan rumusan masalah yang menjadi fokus pembahasan dan penelitian, maka tujuan penelitian ini adalah sebagai berikut :

1. Untuk mengetahui dan menganalisis bagaimanakah akibat hukum terlaksananya Surat Kuasa Membebankan Hak Tanggungan (SKMHT) dalam perjanjian perjanjian kredit perbankan.

2. Untuk mengetahui perlindungan hukum bagi kreditor pemegang Hak Tanggungan yang berupa Hak Guna Bangunan dalam hal jangka waktu haknya berakhir sebelum kreditnya jatuh tempo.

\section{METODE PENELITIAN}

\section{A. Jenis Penelitian}

Menurut Sutrisno Hadi, penelitian atau research adalah usaha untuk menemukan, mengembangkan dan menguji kebenaran suatu pengetahuan, usaha mana dilakukan dengan menggunakan metode-metode ilmiah. ${ }^{13}$

Dengan demikian penelitian yang dilaksanakan tidak lain untuk memperoleh data yang telah teruji kebenaran ilmiahnya. Namun untuk mencapai kebenaran tersebut ada dua buah pola berpikit secara empiris atau melalui

\footnotetext{
12 Florianus SP Sangsun. 2007. Tata Cara Mengurus Sertifikat Tanah. Jakarta: Visi Media. 2007. 5

${ }^{13}$ Soerjono Soekanto. 1986. Pengantar Penelitian Hukum. Jakarta: UI Press. 6.
}

pengalaman. Oleh karena itu untuk menemukan metode ilmiah, maka digabungkanlah metode pendekatan rasional dan metode pendekatan empiris, di sini rasionalisme memberikan kerangka pemikiran yang logis sedang empirisme memberikan kerangka pembuktian atau pengujian untuk memastikan suatu kebenaran. ${ }^{14}$

Menurut Soerjono Soekanto ada dua jenis penelitian hukum, yaitu penelitian hukum normatif dan penelitian hukum empiris. Penelitian hukum normatif atau yang disebut juga penelitian hukum kepustakaan adalah penelitian hukum yang dilakukan dengan cara meneliti bahan pustaka atau data sekunder belaka. Sedangkan penelitian hukum empiris adalah penelitian yang datanya diperoleh secara langsung dari masyarakat yang dinamakan data primer. ${ }^{15}$

Dalam Penelitian ini, tipe penelitian yang dipakai oleh penulis adalah tipe penelitian hukum yuridis normatif dimana tipe penelitian yang dilakukan bertujuan untuk meneliti asasasas hukum dengan menggunakan peraturan perundang-undangan yang berkaitan dengan permasalahan dan untuk mengetahui bagaimanakah perlindungan hukum terhadap kreditur dalam hal, kredit dari debitur yang dijaminkan di bank dalam bentuk Hak Tanggungan dalam hal ini objeknya adalah Hak Guna Bangunan, habis masa berlakunya sebelum masa kredit jatuh tempo.

\section{B. Sumber Pengumpulan Data}

Sumber data pada penelitian hukum normatif adalah sekunder yang diperoleh dan dikumpulkan dari bahan hukum primer, bahan hukum sekunder, dan bahan hukum tersier atau penunjang $^{16}$

\section{Metode Pendekatan}

Metode pendekatan dalam penelitian hukum normatif peulisan ini meliputi:

\footnotetext{
${ }^{14}$ Ronny Hanitijo Soemitro. 1990. Metodologi Penelitian Hukum dan Jurimetri, Jakarta: Ghalia Indonesia. 36.

${ }^{15}$ Soerjono Soekanto, Sri Mamuji, Penelitian Hukum Normatif Suatu Tinjauan Singkat. (jakarta : PT. Raja Grafindo Persada 2015) cetakan ke- 17, 12-14.

${ }^{16}$ Soerjano Soekanto dan Sri Mamudji. 2005. Penelitian Hukum Normatif Suatu Tinjauan Singkat. Cetakan V. Jakarta: Raja Grafindo Persada. 24
} 
Pendekatan ini dilakukan dengan cara menelaah, menganalisis, semua peraturan perundang-undangan yang berkaitan dengan isu perlindungan hukum terhadap kreditur yang disebabkan oleh wanprestasi dari debitur.

2. Pendekatan konseptual (conseptual approach);

Pendekatan konseptual dilakukan untuk memahami konsep-konsep mengenai isu hukum masalah yang sedang dikaji, sehingga diharapkan pernormaan dalam aturan hukum, tidak lagi ada ambigu dan kabur. ${ }^{17}$

\section{Teknik Pengumpulan dan Analisis Data}

Bahan hukum yang dikaji dan yang dianalasis dalam penelitian hukum normatif meliputi bahan hukum primer, sekunder dan tersier. Teknik untuk mengkaji dan mengumpulkan ketiga bahan itu, yaitu menggunakan studi dokumenter. Studi dokumenter merupakan studi yang mengkaji tentang berbagai dokumendokumen, baik yang berkaitan dengan peraturan perundang-undangan maupun dokumendokumen yang sudah ada. ${ }^{18}$

Analisis data yang digunakan adalah analisis kualitatif. Analisis kualitatif merupakan analisis data yang tidak menggunakan angka, melainkan memberikan gambaran-gambaran (deskripsi) dengan kata-kata atas temuan-temuan, dan karenanya ia lebih mengutamakan mutu/kualitas dari data, dan bukan kuantitas. ${ }^{19}$

\section{HASIL DAN PEMBAHASAN}

\section{A. Akibat Hukum Terlaksananya Surat Kuasa Membebankan Hak Tanggungan (SKMHT) Dalam Perjanjian Kredit Perbankan}

Dalam praktek sehari-hari pembuatan SKMHT dibuat guna menjadi jembatan untuk mewujudkan pembuatan APHT dikemudian hari dikarenakan pada saat itu APHT belum dapat dibuat sehingga terpaksa dibuat SKMHT lebih dahulu, misal pada saat pembuatan akta perjanjian kredit seharusnya dilanjutkan dengan pembuatan APHT namun karena sertifikat sedang dalam proses peralihan hak atau sedang

\footnotetext{
17 Johnny Ibrahim. 2007. Teori dan Metodologi Penelitian Hukum Normatif. Surabaya Bayumedia Publishing. Cetakan ke-3. 391

${ }^{18}$ H. Salim HS, Erlies Septiana Nurbani. op.cit. 19.

19 Ibid.
}

dalam proses peroyaan menyebabkan APHT tidak dapat dibuatkan saat itu. Bila kreditur setuju maka saat itu dibuat saja akta perjanjian kredit dan SKMHT sedangkan APHT akan dibuatkan dikemudian hari yaitu setelah proses peralihan atau proses peroyaan selesai.

SKMHT memberikan kedudukan yang kuat kepada kreditur karena SKMHT tidak dapat ditarik kembali dan dan tidak dipergunakan atau karena telah habis jangka waktunya. Oleh sebab itu kreditur tidak perlu merasa khawatir akan kekuatan SKMHT, yang perlu diperhatikan adalah masa berlakunya SKMHT karena SKMHT akan gugur demi hukum bila masa berlakunya berakhir. Disarankan agar PPAT mempunyai daftar atau catatan khusus tentang semua SKMHT yang dibuatnya sehingga mudah dikontrol untuk mengetahui kapan berakhirnya masa berlaku SKMHT yang dibuatnya. SKMHT yang telah berakhir masa berlakunya tidak dapat dipergunakan lagi sebagai alas hak untuk membuat APHT bila hal ini terjadi maka dapat menimbulkan kelemahan/potensi kerugian pada kreditur. Harus diingatkan bahwa SKMHT yang telah habis masa berlakunya menyebabkan SKMHT gugur demi hukum dengan demikian dapat disimpulkan bahwa masa berlaku SKMHT tidak dapat diperpanjang oleh karena itu PPAT harus sungguh-sungguh memperhatikan dan memperhitungkan masa berlakunya SKMHT sehingga menghindarkan diri dari tidak dapat dibuatnya APHT yang dikarenakan telah berakhirnya masa berlakunya SKMHT. ${ }^{20}$

Penggunanaan SKMHT yang lahir dari perjanjian kredit terjadi karena kreditur yakin pinjamannya akan aman dikarenakan jaminan yang di berikan debitur adalah berupa hak atas tanah yang dipasang SKMHT serta kreditur yakin akan kemampuan debitur dalam mengembalikan kredit sesuai kesepakatan. Keuntungan yang diproleh dari penggunaan SKMHT adalah kredit yang di berikan oleh kreditur menjadi lebih terjamin. Kredit tersebut terjamin dikarenakan diberikannya hak dan kekuasaan kepada bank untuk mendapat pelunasan dari agunan apa bila debitur melakukan cidera janji, yaitu untuk membayar kembali utangnya pada waktu yang telah di tentukan dalam perjanjian,dan adanya kepastian hukum kepada pihak Bank bahwa kreditnya

\footnotetext{
${ }^{20}$ Ibid. 248
} 
akan tetap kembali dengan cara mengesekusi jaminan kreditnya. ${ }^{21}$

Pembuatan SKMHT dilatarbelakangi berbagai kepentingan dan hambatan, terutama karena proses pembebanan, pemberian, dan pemasangan Hak Tanggungan tidak mudah antara lain disebabkan hal-hal sebagai berikut: ${ }^{22}$

a. Harus melalui suatu formalitas tertentu;

b. Memakan waktu yang lama relatif cukup lama;

c. Memerlukan biaya pembebanan yang relatif cukup tinggi

d. Kredit yang diberikan oleh kreditur kepada debitur jangka waktunya pada dasaraya terlalu singkat dan jumlahnya juga tidak terlalu besar

e. Benda yang akan dijaminkan belum bersertifikat;

f. Kreditur mempercayai debitur, artinya ia merasa terjamin bilamana telah mendapat kuasa dari debitur untuk memasang Hak Tanggungan. Sebaliknya, debitur juga merasa tertolong dan aman dengan dipasangnya hak tanggungan oleh pihak kreditur;

g. Pemberi hak tanggungan terkadang tidak dapat hadir sendiri di hadapan Notaris/PPAT untuk membuat APHT.

Pada dasarnya, pemberian kuasa diberikan dalam bentuk perjanjian antara pemberi kuasa dan penerima kuasa untuk melakukan suatu tindakan atau urusan tertentu. Oleh karena itu, terkait dengan keabsahan pemberian kuasa juga harus memuat syarat sahnya suatu perjanjian. Dimana dalam perjanjian, terdapat syarat subjektif yaitu sepakat mereka yang mengikatkan dirinya dan kecakapan untuk membuat suatu perjanjian, kemudian syarat objektif yaitu suatu hal tertentu dan suatu sebab yang halal. Ketentuan mengenai syarat subjektif dan syarat objektif yang berlaku pada umumnya dalam pemberian kuasa, pada dasarnya berlaku juga dalam pembuatan SKMHT. Hal tersebut dikarenakan, substansi yang termuat dalam SKMHT berdasarkan peraturan perundang-

\footnotetext{
${ }^{21}$ I Gusti Nyoman Kusuma Primayadnya. 2019. Pelaksanaan Perjanjian Kredit Bank Dengan Surat Kuasa Membebankan Hak Tanggungan (SKMHT) di Kabupaten Tabanan. Jurnal Ilmu Hukum. Nomor 11: 7. 7

${ }^{22}$ Rachmadi Usman. 2013. Hukum Kebendaan. Jakarta: Sinar Grafika. 347
}

undangan termasuk dalam kategori pemberian kuasa. $^{23}$

Kewenangan Notaris dalam jabatannya bersumber pada Undang-Undang, sebagai kewenangan atribusi yang diberikan oleh Undang-Undang, yang dalam hal ini pada dasarnya berwenang membuat akta autentik sebagaimana yang diatur dalam UU No. 30 tahun 2004 sebagaimana telah diubah dengan UU No. 2 tahun 2014. Kehadiran Notaris sebagai pejabat umum dalam membuat akta autentik memang diperlukan, agar menjamin keautentikan suatu keadaan, peristiwa, atau perbuatan yang diselenggarakan, sehingga dapat menjamin kepastian, ketertiban, dan perlindungan hukum bagi masyarakat dan para pihak yang membutuhkan alat bukti tertulis yang bersifat autentik.

Kewenangan Notaris dalam jabatannya sebagai pejabat umum tersebut diatur dalam Pasal 15 UU No. 30 tahun 2004 sebagaimana telah diubah dengan UU No. 2 tahun 2014, yang menyatakan sebagai berikut:

1) Notaris berwenang membuat Akta autentik mengenai semua perbuatan, perjanjian, dan penetapan yang diharuskan oleh peraturan perundang-undangan dan/atau yang dikehendaki oleh yang berkepentingan untuk dinyatakan dalam Akta autentik, menjamin kepastian tanggal pembuatan Akta, menyimpan Akta, memberikan grosse, salinan dan kutipan Akta, semuanya itu sepanjang pembuatan Akta itu tidak juga ditugaskan atau dikecualikan kepada pejabat lain atau orang lain yang ditetapkan oleh undang-undang.

2) Selain kewenangan sebagaimana dimaksud pada ayat (1), Notaris berwenang pula:
a. mengesahkan tanda tangan dan menetapkan kepastian tanggal surat di bawah tangan dengan mendaftar dalam buku khusus;
b. membukukan surat di bawah tangan dengan mendaftar dalam buku khusus;
c. membuat kopi dari asli surat di bawah tangan berupa salinan yang memuat uraian sebagaimana ditulis dan digambarkan dalam surat yang bersangkutan;

\footnotetext{
${ }^{23}$ Ibid. 440
} 
d. melakukan pengesahan kecocokan fotokopi dengan surat aslinya;

e. memberikan penyuluhan hukum sehubungan dengan pembuatan Akta;

f. membuat Akta yang berkaitan dengan pertanahan; atau

g. membuat Akta risalah lelang.

3) Selain kewenangan sebagaimana dimaksud pada ayat (1) dan ayat (2), Notaris mempunyai kewenangan lain yang diatur dalam peraturan perundang-undangan. ${ }^{24}$

Dalam pembuatan kuasa membebankan Hak tanggungan oleh notaris adalah dalam bentuk akta dibuat dihadapan (ten overstaan) notaris yang berisi uraian atau keterangan, pernyataan para pihak yang diberikan atau yang diceritakan dihadapan notaris. Dalam uraian sebelumnya, telah dijelaskan bahwa pembuatan SKMHT harus memenuhi syarat-syarat secara substantif seperti yang disebutkan dalam UUHT. Disamping syarat substantif, sesungguhnya terdapat pula syarat bentuk dari suatu akta notaris yang harus dipenuhi bersama-sama dengan syarat substantif. Seperti telah dijelaskan di atas bahwa, akta notaris agar dapat dinilai sebagai akta otentik, maka akta tersebut harus dibuat dalam bentuk yang ditentukan undang-undang. Ketentuan undang-undang yang dimaksud adalah ketentuan yang terdapat dalam UUJN. Dalam UUJN, ditentukan bahwa bentuk suatu akta notaris harus terdiri dari:

1. Setiap Akta terdiri atas:
a. Awal Akta atau kepala Akta;
b. Badan Akta; dan
c. Akhir atau penutup Akta.

2. Awal Akta atau kepala Akta memuat:
a. Judul Akta;
b. Nomor Akta;
c. Jam, hari, tanggal, bulan, dan tahun; dan
d. nama lengkap dan tempat kedudukan Notaris.

3. Badan Akta memuat:
a. Nama lengkap, tempat dan tanggal lahir, kewarganegaraan, pekerjaan, jabatan, kedudukan, tempat tinggal para penghadap dan/atau orang yang mereka wakili;
b. Keterangan mengenai kedudukan bertindak penghadap;

\footnotetext{
${ }^{24}$ Rachmadi Usman. Op.cit 229.
}

c. Isi Akta yang merupakan kehendak dan keinginan dari pihak yang berkepentingan;

d. Nama lengkap, tempat dan tanggal lahir, serta pekerjaan, jabatan, kedudukan, dan tempat tinggal dari tiap-tiap saksi pengenal.

4. Akhir atau penutup Akta memuat:

a. Uraian tentang pembacaan Akta sebagaimana dimaksud dalam Pasal 16 ayat (1) huruf $m$ atau Pasal 16 ayat (7);

b. Uraian tentang penandatanganan dan tempat penandatanganan atau penerjemahan Akta jika ada;

c. Nama lengkap, tempat dan tanggal lahir, pekerjaan, jabatan, kedudukan, dan tempat tinggal dari tiap-tiap saksi Akta; dan

d. Uraian tentang tidak adanya perubahan yang terjadi dalam pembuatan Akta atau uraian tentang adanya perubahan yang dapat berupa penambahan, pencoretan, atau penggantian serta jumlah perubahannya.

5. Akta Notaris Pengganti dan Pejabat Sementara Notaris, selain memuat ketentuan sebagaimana dimaksud pada ayat (2), ayat (3), dan ayat (4), juga memuat nomor dan tanggal penetapan pengangkatan, serta pejabat yang mengangkatnya. ${ }^{25}$

Bentuk dari akta notaris wajib memenuhi ketentuan seperti disebutkan pada di atas. Sehingga terdapat konsekuensi hukum, apabila salah satu unsur ketentuan tersebut tidak tercantum dalam suatu akta notaris. SKMHT sebagai akta notaris dan agar terpenuhi sebagai akta otentik juga harus memenuhi ketentuan tersebut. Sehingga SKMHT mempunyai kekuatan pembuktian yang sempurna sebagai akta otentik. Konsekuensi hukum merupakan akibat yang timbul dari dilaksanakannya atau tidak dilaksanakannya suatu ketentuan hukum dalam sebuah perbuatan hukum. Dalam hal, tidak terpenuhinya seluruh ketentuan UUJN oleh Notaris saat pembuatan suatu akta, maka konsekuensi hukumnya adalah terdegradasinya akta tersebut menjadi akta di bawah tangan setelah akta itu ditandatangani. Secara normatif, dalam Kitab Undang-Undang Hukum Perdata

\footnotetext{
${ }^{25}$ Ketentuan Pasal 38 Undang-Undang Nomor 2 Tahun 2014.
} 
sebagai lex generali dari akta otentik dan UUJN sebagai lex spesialis akta otentik yang dibuat notaris, sesungguhnya telah mengatur mengenai "sanksi" terhadap akta yang pembuatannya tidak memenuhi ketentuan yang berlaku. ${ }^{26}$

\section{B. Perlindungan Hukum Terhadap Kreditur Pemegang Hak Tanggungan yang Obyeknya Berupa Hak Guna Bangunan yang Akan Berakhir Sedangkan Jangka Waktu Kreditnya Belum Jatuh Tempo}

Perlindungan hukum yang diberikan kreditur sebagai pemegang Hak Tanggungan yang mempunyai preferensi dari kreditur lainnya apabila ada jaminan dengan status Hak Guna Bangunan yang akan atau telah jatuh tempo, dapat dilakukan dari 3 (tiga) aspek, yaitu : ${ }^{27}$

1. Aspek sebelum pengikatan kredit dilakukan yang merupakan tindakan preventif dari pihak bank;

Khusus mengenai tanah dengan status Hak Guna Bangunan, dapat diterima sebagai jaminan kredit, dengan syarat kredit tersebut jangka waktunya lebih, dan jatuh tempo hak tersebut dimungkinkan juga, namun diberikan dengan selektif dan mengingat sifat kredit tersebut, apakah bisa diperpanjang atau tidak. Selama kredit tersebut diperpanjang (revolving), tentu akan mudah bagi bank untuk memantau jatuh tempo Hak Guna Bangunan tersebut, karena setiap kali diperpanjang selalu ada review dari Analis, Taksasi, dan Legal. Lain halnya jika kredit tidak diperpanjang (unrevolving), tentu memerlukan perhatian khusus, karena bila sampai berakhir haknya, sedangkan kredit belum berakhir, pihak bank di sini tentu akan mengalami kerugian karena hanya berkedudukan sebagai kreditur konkuren, yang hanya berhak atas bangunan yang berdiri di atas tanah yang menjadi jaminan, sedangkan hak atas tanah tersebut kembali kepada negara.

Untuk kredit yang diberikan dengan sifat dapat diulang (revolving), seperti dalam bentuk kredit modal kerja yang berupa Kredit Rekening Koran, Kredit Fixed Loan, dan Kredit Demand Loan, akan memberikan kemungkinan diterimanya HGB yang hampir jatuh tempo, meskipun jatuh tempo hak tersebut tinggal satu tahun. Namun perlu dicatat disini, jika kredit tersebut adalah kredit baru, maka perpanjangan hak dilakukan bersamaan dengan saat pemasangan Hak Tanggungan atas jaminan tersebut. Proses pemasangan Hak Guna Bangunan yang akan jatuh tempo dilakukan langsung setelah proses pembebanan Hak Tanggungan selesai, dimana pihak bank akan mengeluarkan surat persetujuan untuk memperpanjang Hak Guna Bangunan tersebut, karena masih dijadikan jaminan pada bank. Apabila kredit tersebut tergolong kredit lama dan akan diulang ataupun diperpanjang tiap tahun, review terhadap jaminan yang akan jatuh tempo tentu akan selalu diberikan setiap kali kredit akan diperpanjang, agar jangan sampai hak tersebut berakhir tidak diperpanjang oleh bank. Jadi disini pihak bank akan mengharuskan pihak debitur untuk memperpanjang hak tersebut apabila menghendaki kredit tersebut akan diulang atau diperpanjang. Biasanya debitur memberikan kuasa kepada bank untuk memperpanjang hak tersebut yang bertujuan agar kredit yang diadakan oleh bank dengan debitur tetap dijamin dengan Hak Tanggungan. Berdasarkan segi kreditur, dengan adanya perpanjangan SHGB tersebut, maka kredit yang diberikan oleh bank akan tetap dijamin oleh SHGB yang telah diperpanjang. Dari segi debitur, maka debitur tetap memiliki tanah tersebut, karena dengan diperpanjang hak tersebut, tanah tidak jatuh ke negara.

2. Menurut Pasal 26 ayat (1) dan (2) PP No. 40 Tahun 1996 tentang Hak Guna Usaha, Hak Guna Bangunan dan Hak Pakai Atas Tanah, atas permohonan pemegang haknya Hak Guna Bangunan atas tanah Negara dapat diperpanjang jika :

a. Tanahnya masih dipergunakan dengan baik sesuai dengan keadaan, sifat dan tujuan pemberian hak tersebut;

\footnotetext{
${ }^{26}$ Made Oka Cahyadi Wiguna Op.cit. 443-444.

${ }^{27}$ Evani Rahayu. Ibid, 250.
} 
b. Syarat-syarat pemberian hak tersebut dipenuhi dengan baik oleh pemegang hak;

c. Pemegang hak masih memenuhi syarat sebagai pemegang hak, yaitu Warga Negara Indonesia dan Badan Hukum yang didirikan menurut hokum Indonesia dan berkedudukan di Indonesia;

d. Tanah tersebut masih sesuai dengan Rencana Tata Ruang Wilayah yang bersangkutan;

e. Hak Guna Bangunan atas tanah Hak Pengelolaan diperpanjanag atau diperbarui atas permohonan pemegang Hak Guna Bangunan setelah mendapat persetujuan dari pemegang Hak Pengelolaan.

f. Menurut Pasal 30 sub a PP No.40 Tahun 1996 tentang Hak Guna Usaha, Hak Guna Bangunan dan Hak Pakai Atas Tanah, pemegang Hak Guna Bangunan berkewajiban membayar uang pemasukan yang jumlah dan cara pembayarannya ditetapkan dalam keputusan pemberian haknya. ${ }^{28}$

Apabila debitur menolak jangka waktu kredit yang diperpendek sebagai akibat Hak Guna Bangunan yang akan jatuh tempo, pihak bank memberikan 2 (dua) altematif, yaitu :

a. Merubah Hak Guna Bangunan tersebut menjadi Hak Milik;

b. Memperpanjang Hak Guna Bangunan tersebut, segera setelah pengikatan kredit dilakukan.

Apabila debitur dalam hal ini tidak melaksanakan pembayaran angsuran kredit selama 3 bulan berturut-turut, atas fasilitas kredit yang telah diberikan kreditur (Bank) tersebut digolongkan sebagai kredit macet. Dalam prakteknya, penyelesaian kredit bermasalah oleh kreditur dilakukan dengan cara ganti rugi. Wanprestasi diatur pada Pasal 1243 KUHPerdata menyatakan "Penggantian biaya, kerugian, dan bunga karena tidak dipenuhinya suatu perikatan mulai diwajibkan, bila debitur, walaupun telah dinyatakan lalai untuk memenuhi perikatan itu, tetap melalaikannya, atau jika sesuatu yang harus diberikan atau dibuatnya dalam tenggang waktu yang telah

\footnotetext{
${ }^{28}$ Eka Widya Retno Sari. Op.cit. 99-100.
}

dilampaukannya".Sedangkan Pasal 1244 KUHPerdata menyatakan"Debitur harus dihukum untuk mengganti biaya, kerugian dan bunga, bila ia tidak dapat membuktikan bahwa tidak dilaksanakannya perikatan itu atau tidak tepat waktu dalam melaksanakan perikatan itu disebabkan oleh sesuatu hal yang tak terduga, yang tidak dapat dipertanggungkan kepadanya, walaupun tidak ada itikat buruk kepadanya". ${ }^{29}$

Terhadap kredit yang telah berjalan, tidak tertutup kemungkinan bagi debitur yang ingin merubah status tanahnya yang semula Hak Guna Bangunan menjadi Hak Milik, karena memang dimungkinkan oleh Keputusan Menteri Negara Agraria/Kepala Badan Pertanahan Nasional Nomor 6 Tahun 1998 tentang Pemberian Hak Milik atas Tanah untuk rumah tinggal. Upaya preventif lainnya adalah terhadap permohonan yang diajukan oleh debitur, pihak bank akan mempertimbangkan terlebih dahulu apakah debitur tersebut lancar dalam pembayaran kreditnya, agar tidak timbul akibat yang tidak diinginkan dikemudian hari. Bank juga dapat meminta jaminan tambahan maupun jaminan pengganti. Langkah ini diambil oleh bank, karena bank merasa dengan jaminan yang diberikan oleh debitur masih tidak mencukupi ataupun karena alasan lain yang mengharuskan meminta jaminan tambahan ataupun jaminan pengganti. Jaminan tambahan diminta oleh pihak bank, karena dengan jaminan utama yang diberikan oleh debitur belum mencukupi untuk menjamin utang/ kreditnya. Biasanya jaminan tambahan ini berupa barang bergerak seperti mobil, maupun asset berupa mesin/ ${ }^{30}$ stok barang, yang pengikatannya dilakukan secara fidusia maupun berupa deposit yang ada pada bank tersebut, yang pengikatannya dilakukan secara gadai bawah tangan dilengkapi dengan kuasa dari debitur kepada bank untuk memblokir, memperpanjang maupun mencairkan deposito tersebut. Jaminan pengganti diminta oleh bank, karena jaminan yang diberikan oleh debitor tidak dapat diterima oleh bank sebagai jaminan kredit. Mengenai Hak Guna Bangunan yang akan jatuh tempo, pihak bank dapat juga meminta jaminan pengganti.

\footnotetext{
${ }^{29}$ Mitia Intansari. 2017. Kedudukan Kreditur Pemegang Hak Tanggungan Dalam Hal Debitur Wanprestasi. Journal IImu Hukum. Nomor 2: 5.5

${ }^{30}$ Lushun Adji Dharmanto. Op.cit. 250.
} 
Kasus yang terjadi di Bank BRI cabang Manado, dimana jaminan kredit Hak Tanggungan yang Obyeknya Berupa Hak Guna Bangunan, yang akan berakhir pada Desember 2018 sedangkan jangka waktu kreditnya jatuh tempo pada Juli 2019 dan juga sementara pihak Bank hanya sebagai pemegang SKMHT.

Dalam wawancara dengan salah satu Pegawai Legal Officer di Bank BRI cabang Manado, pihak Bank telah melakukan upaya preventif dan represif untuk mencegah hapusnya Hak Tanggungan berupa Objeknya Hak Guna Bangunan yang akan berakhir masa berlakunya sebelum Kredit jatuh tempo, upaya preventif tersebut adalah menurut peraturan Bank BRI dimana setiap nasabah yang ingin mengajukan kredit harus mengisi formulir permohonan kredit secara lengkap dengan dilampiri data kemudian dilakukan analisis dan dievaluasi, dengan tetap memperhatikan faktor 5C (character, capacity, capital, collateral, dan condition of economy), 3P (purpose, prospect, dan payment), serta 3R (returns, repayment, dan risk bearing ability).

Adapun upaya preventif lainnya sebagai berikut:

a. Menentukan jangka waktu kredit yang akan diberikan;

b. Menentukan berapa lama kredit akan diberikan berdasarkan sisa jangka waktu jatuh tempo Hak Guna Bangunan yang dijadikan agunan kredit.

Upaya preventif ini dapat melindungi pihak bank dari tejadinya wanprestasi debitur. Dengan menganut prinsip kehati-hatian bank, pihak bank dapat memeriksa formulir kelengkapan kredit tersebut sehingga sebelum agunan Hak Guna Bangunan habis masa berlaku, pihak bank sudah bisa menghubungi pihak debibur untuk memperpanjang masa berlaku Hak Guna Bangunan tersebut.

Dalam kasus tersebut selain telah dilakukannya upaya preventif, pihak bank juga telah melakukan upaya represif dimana debitur mempunyai itikad baik yaitu telah membuat surat pernyataan bahwa sebelum masa kredit selesai, debitur akan mengganti SKMHT yang dipegang oleh bank dengan membuat APHT dihadapan pejabat pembuat akta tanah yaitu Notaris, dan lalu setelah APHT selesai dibuat, debitur akan memberikan kewenangan kepada bank sebagai kreditur untuk memperpanjang masa berlaku Hak Guna Bangunan tersebut.
Biaya yang dipakai untuk perpanjangan masa waktu Hak Guna Bangunan tersebut dilimpahkan/ ditanggung oleh debitur, namun apabila debitur belum mempunyai dana untuk membayar pada saat itu, bank bersedia membayarnya terlebih dahulu lalu dikemudian hari ketika masa kredit dari debitur jatuh tempo, biaya tersebut akan ditambah di dalam jumlah piutang dari debitur. Sehingga tidak akan menyebabkan kredit macet dan tidak akan menyebabkan Hak Tanggungan tersebut batal demi hukum. ${ }^{31}$

Bank juga dapat meminta jaminan pengganti kepada debitur tersebut dikarenakan pihak bank merasa bahwa dengan jaminan yang diberikan oleh pihak debitur tidak mencukupi ataupun karena dengan alasan lain sehingga diperlukan jaminan pengganti. Meminta jaminan pengganti kepada debitur terhadap jaminan kredit utamanya berupa tanah dengan status Hak Guna Bangunan yang jangka waktu haknya terbatas serta akan berakhir. Pentingnya adanya jaminan pengganti ini karena jika jangka waktu Hak Guna Bangunan tersebut berakhir, maka Hak Tanggungan yang membebaninya juga ikut hapus. Selain itu dapat juga guna menjamin kepastian pengembalian kreditnya apabila debitur wan prestasi. Hal ini dilakukan mengingat ketentuan perundang-undangan telah mengatur dengan tegas bahwa dengan berakhirnya Hak Guna Bangunan, Hak Tanggungan yang membebaninya juga ikut hapus. Selain itu juga untuk mengantisiapsi jika proses perpanjangan dari Hak Guna Bangunan tersebut ditolak atau tidak dapat diperpanjang.

\section{PENUTUP}

\section{A. Kesimpulan}

1. SKMHT dibuat oleh notaris atau PPAT dan dapat dipergunakan dalam hal pemberi hak tanggungan berhalangan hadir dalam memberikan hak tanggungan dan menandatangani APHT sehingga dikuasakan kepada pihak lain. Jangka waktu berlakunya SKMHT adalah satu bulan dalam hal dijadikan objek hak tanggungan hak atas tanah yang sudah didaftar, dan tiga bulan untuk jaminan hak atas tanah yang belum didaftar atau bilamana hak atas tanah yang

\footnotetext{
${ }^{31}$ Wawancara dengan SJ Pegawai Legal Officer di Bank BRI cabang Manado
} 
bersangkutan sudah bersertifikat, tetapi belum tercatat atas nama pemberi hak tanggungan sebagai pemegangnya hak yang baru. Pembebanan hak tanggungan untuk tanah-tanah yang sudah terdaftar (ada sertifikat) didahului dengan pembuatan APHT oleh PPAT, yang kemudian berdasarkan APHT tersebut oleh Kantor Pertanahan dikeluarkan sertifikat hak tanggungan. Untuk tanahtanah yang belum terdaftar dan tanahtanah yang berada diluar wilayah kerja kreditur, pembebanan hak tanggungannya adalah dalam bentuk SKMHT yang juga dibuat oleh Notaris/PPAT.

2. Kreditur pemegang Hak Tanggungan yang objeknya tanah dengan status Hak Guna Bangunan yang berakhir sebelum kreditnya jatuh tempo tidak mendapat perlindungan hukum berdasarkan UUHT.

\section{B. Saran}

1. Akibat hukum dari berlakunya SKMHT ini merupakan perbuatan hukum yang telah dilakukan sesuai dengan peraturanperaturan perundang-undangan yang berlaku. Namun hendaknya para pihak khususnya kreditur agar mempertimbangkan penggunaan SKMHT dalam hal debitur meminjam kredit, karena perbedaan dari segi fungsi antara SKMHT dan APHT, perbedaan dari segi jangka waktu berlakunya maupun tentang perbedaan kedudukan kreditur pada SKMHT dan APHT. Sehingga kreditur dapat menilai apakah nilai kredit tersebut sesuai bila digunakan SKMHT atau langsung dengan APHT.

2. Bank pemberi kredit harus waspada dalam menerima jaminan dengan Hak Guna bangunan yang jangka waktu haknya berakhir sebelum kreditnya jatuh tempo, sebab bila hak atas tanahnya hapus maka Hak Tanggungannya akan ikut hapus. Untuk mengantisipasi hal tersebut maka bank pemberi kredit harus: Meminta kuasa dari pemilik jaminan dan semua dokumen untuk proses perpanjangan hak atas tanah yang dijadikan jaminan, Perpanjangan hak tersebut kiranya mulai diurus jauh sebelum jangka waktunya habis, Apabila ternyata HGB tersebut tidak dapat diperpanjang lagi, sedangkan debitur tidak dapat melunasi hutangnya dengan seketika lunas, bank segera meminta jaminan pengganti.

\section{DAFTAR PUSTAKA}

Sony Harsono. 1996. Sambutan Menteri Agraria/ Kepala BPN Dalam Seminar Hak Tanggungan atas Tanah dan Bendabenda yang Berkaitan dengan Tanah. Fakultas Hukum UNPAD. Bandung.

Nindyo Pramono. 2006. Hukum Bisnis Aktual. Cetakan Kesatu . Bandung: Citra Aditya Bakti.

Adrian Sutedi. 2006. Implikasi Hak Tanggungan Terhadap Pemberian Kredit Oleh Bank dan Penyelesaian Kredit Bermasalah. Jakarta: Cipta Jaya.

Retnowulan Sutantio 1999. Penelitian Tentang Perlindungan Hukum Eksekusi Jaminan Kredit. Jakarta: Badan Pembinaan Hukum Nasional-Departemen Kehakiman RI.

Kansil. Pokok-Pokok Hak Tanggungan Atas Tanah. 2009. Jakarta: Pustaka Sinar Harapan.

M. Isnaeni. 1999. Kerancuan Hak Tanggungan Dalam Kaitannya Sebagai Pengamanan Penyaluranan Kredit Bank. Jurnal Hukum Hak Tanggungan. Vol. I. Jakarta.

Juhaenda Hasan. 2000. Aspek Hukum Jaminan Kebendaan dan Perorangan, Jurnal Hukum Bisnis. Nomor 16: 11.

Florianus SP Sangsun. 2007. Tata Cara Mengurus Sertifikat Tanah. Jakarta: Visi Media. 2007.

Soerjono Soekanto. 1986. Pengantar Penelitian Hukum. Jakarta: UI Press.

Ronny Hanitijo Soemitro. 1990. Metodologi Penelitian Hukum dan Jurimetri, Jakarta: Ghalia Indonesia.

Soerjono Soekanto, Sri Mamuji, Penelitian Hukum Normatif Suatu Tinjauan Singkat. (jakarta : PT. Raja Grafindo Persada 2015) cetakan ke- 17, 12-14.

Johnny Ibrahim. 2007. Teori dan Metodologi Penelitian Hukum Normatif. Surabaya Bayumedia Publishing. Cetakan ke-3.

I Gusti Nyoman Kusuma Primayadnya. 2019. Pelaksanaan Perjanjian Kredit Bank Dengan Surat Kuasa Membebankan Hak 
Tanggungan (SKMHT) di Kabupaten Tabanan. Jurnal Ilmu Hukum. Nomor 11: 7.

Rachmadi Usman. 2013. Hukum Kebendaan. Jakarta: Sinar Grafika.

Mitia Intansari. 2017. Kedudukan Kreditur Pemegang Hak Tanggungan Dalam Hal Debitur Wanprestasi. Journal IImu Hukum. Nomor 2. 